\title{
The Influence of Students' Reading Interest on Writing Ability in Learning Indonesian
}

\author{
Sela Dwi Anjani \\ Bengkulu State Islamic Institute \\ seladwianjani8@gmail.com \\ Sukarno \\ Bengkulu State Islamic Institute \\ upma.sukarno@gmail.com \\ Vebbi Andra \\ Bengkulu State Islamic Institute \\ vebbiandra@yahoo.com
}

\begin{abstract}
The problems discussed in this study aim to determine whether there is an effect of reading interest in science majors on writing skills in learning Indonesian at SMA Negeri 5 Lebong. The approach in this research is quantitative and the type of research used is regressional. The population of this study were students majoring in science at SMA Negeri 5 Lebong and the sample of this study amounted to 65 students. The variables in this study consisted of the independent variable, namely reading interest and the dependent variable, namely the ability to write. The data collection technique was carried out by distributing a questionnaire (questionnaire) for the variable $\mathrm{X}$ and a poetry writing test for the $\mathrm{Y}$ variable. For testing the validity and reliability of this study using the SPSS version 20 program. Based on the results of data analysis, the $t_{-}$count value obtained is 5.519 and the $t_{\text {table }}$ is 1.998 , then the $\mathrm{t}_{\text {count }}$ value is $5.519>$ from $\mathrm{t}{ }_{\text {table }} 1.998$, so it can be concluded that $\mathrm{H}_{\circ}$ rejected and $\mathrm{H}_{\mathrm{a}}$ acceptability which means "There is the influence of interest in reading (X) on the ability to write (Y) in the Indonesian language learning in SMAN 5 Lebong".
\end{abstract}

Keywords: Reading Interest, Writing Ability, Indonesian

\section{A. Introduction}

Interest in reading is one of the problems faced in Indonesia. Reading interest is a mental tendency that encourages someone to do something about reading. Interest in reading is indicated by a strong desire to carry out reading activities. People who have a high interest in reading always fill their spare time by reading (Darmono, 2001). A data from UNESCO survey results mentions the interest in reading Indonesian people. The survey shows that Indonesian people's interest in reading is very low. In 2006, Indonesian people's interest in reading was at the lowest position in the Asian region. Meanwhile, International Educational Achievement noted that the reading ability of Indonesian students was the lowest in the ASEAN region. The conclusion was drawn from a study of 39 countries, Indonesia ranks 38th (Ngainun Naim, 2013) .

From these data, it shows how alarming the state of interest in reading in our country is because only by liking reading someone will gain knowledge. However, this data can also be an impetus for all parties to evaluate and make a movement so that all people love to read 
or have a reading tradition. Reading is an activity that has various benefits, reading is done to obtain information or messages conveyed by an author. By reading, we can get various benefits ranging from information, insight, knowledge, experience, and so on.

Interest in reading grows from the personality of each person, so to increase interest in reading, it is necessary to be aware of each individual (Suharmono Kasiyun, 2015) . To build reading habits, it can be started from the family environment, especially parents because children should have been introduced to reading since childhood so that reading activities will become a habit (Ngainun Naim, 2013). If reading has become a habit, then children will not feel bored and lazy when reading and reading activities will be something fun.

With the growth of interest in reading in children, it will improve reading skills gradually. By reading, we will get various benefits, ranging from obtaining information, knowledge or insight, experience, developing creativity, becoming a better person, and being able to improve the quality of our lives. If there is no interest in reading in the child, then reading will not become a habit, not interesting, and will feel boring.

Every child (student) should be aware of the importance of reading activities because by reading, we will get various benefits. In developing reading skills, it should be followed by writing activities. Because reading and writing are a unit that will be good if done together. Language skills that exist in a person are required to be able to express ideas or thoughts, and experiences in the form of writing. Writing is defined as an activity of delivering messages (communication) using written language as a medium (Dalman, 2015). In writing, ideas or thoughts are obtained from reading activities. The ideas that we have in our minds are meaningless if they are only in our minds or our heads. With the presence of excessive interest or interest from within students to continue reading, it will affect the high writing ability of students in learning Indonesian. High reading interest will help students improve writing skills in learning in writing, and the writing will certainly be read by others.

Based on the initial observations made by the author on students majoring in science at SMA Negeri 5 Lebong, it can be seen that many students have low reading interest. The interest in reading has not been inherent among the students. Many factors cause interest in reading in students is low. One of them is because there are still many students who make the wrong use of technology, students prefer watching, playing mobile phones, playing games rather than reading. Ironically they are actually happier and find it easier to search from the internet when there is an assignment from school, without reading it first, they just download the data they need for school work and then collect it. Students also feel that reading is a boring and foreign activity for them, because the interest in reading in these students is not instilled since childhood. 
In addition, learning in schools still does not emphasize students to do reading activities, the learning applied by teachers mostly only focuses on providing materials and does not help students to grow and develop interest in reading. In addition to students' low interest in reading, writing skills in Indonesian language learning are also low because they are not accustomed to writing in Indonesian language learning, students find it difficult to reflect on their ideas to arrange words into writing because they still know little vocabulary. Therefore, students need to be accustomed to reading in order to master various vocabularies that can make it easier for students to write.

Seeing these conditions is an illustration of the problems that exist in students at SMA Negeri 5 Lebong. Therefore, the author is interested in conducting a form of research entitled "The Effect of Reading Interest in Science Department Students on Writing Ability in Indonesian Language Learning at SMA Negeri 5 Lebong"

\section{B. Research Methodology}

This research approach uses a quantitative approach. Quantitative research is research whose data is in the form of numbers and analysis using statistics (Sugiyono, 2019). While the type of research used in this study, this research includes the type of regression research. Regression research is one type of research to determine the level of influence of one variable on other variables (Riduwan, 2019). The population is the total number consisting of objects or subjects that have certain characteristics and qualities determined by the researcher to be studied and then draw conclusions (V. Wiranta Sujarweni, 2020). The population in this study were all students majoring in science at SMA Negeri 5 Lebong, totaling 189 students. The sample is part of a number of characteristics possessed by the population used for research. (V. Wiranta Sujarweni, 2020). The sampling technique used is proportionate stratified random sampling. The sample taken in this study amounted to 65 students.

The data collection technique used in this study was a questionnaire and an essay test. The questionnaire used by the author is a questionnaire that has been tested for validity, reliability, and the correctness of the language so that a valid, valid, and correct questionnaire is obtained in terms of language. The total number of questionnaires for the variable $\mathrm{X}$ (reading interest) is 50 items. Meanwhile, the $\mathrm{Y}$ variable writing ability test (writing ability) is writing poetry. To get a good questionnaire (questionnaire), the author conducted several instrument truth tests, namely by testing the validity of the instrument and testing the reliability. The researcher uses the assistance of the Statistical Product and Service Solutions (SPSS) version 20 application. The $\mathrm{r}$ table value for respondents 23 students is 0.413. If $r$ count is greater than $r$ table, then it can be said to be valid. From the calculation of validity, it is known that the results of the validity of the questionnaire for the variable $\mathrm{X}$ (reading interest), of the 50 questionnaire items that were declared valid, 26 questionnaire 
items were found. So of the 26 valid items will be continued for research. Meanwhile, the Y variable (writing ability) was carried out with a poetry text writing ability test that had been declared valid by the validator so that it was feasible to be used in this study.

Testing the reliability of the variable reading interest instrument was carried out using the Cronbach's Alpha method using the help of the Statistical Product and Service Solutions (SPSS) application version 20 of the 26 valid questionnaire items for the $\mathrm{X}$ variable (reading interest) . then the reading interest instrument is declared reliable. Meanwhile, the $Y$ variable (writing ability) was carried out by means of a poetry text writing ability test that was declared reliable by the validator and was feasible to be used in this study.

The data analysis technique is the method used to analyze the data that has been generated in the study ( Asep Saeful Muhtadi , 2017 ). In this study, the author uses a simple regression analysis technique. Before conducting data analysis, the authors conducted descriptive statistical tests and test requirements analysis first. Descriptive statistical tests are used to find the results of several components including the number of samples, mean, median, standard deviation mode, maximum value, and minimum value. Test requirements analysis which includes homogeneity test, normality test and linearity test. To simplify the calculation of homogeneity, normality, linearity, the authors are assisted by the application of Statistical Product and Service Solutions (SPSS) version 20. After doing these three tests, then the authors test the research problem using a simple regression test. Simple regression can be analyzed because it is based on a functional relationship or causal relationship (causal) of the independent variable (X) to the dependent variable (Y) (Riduwan, 2019) .

\section{Results and Discussion}

\section{Results}

The study has two variab el, namely interest in reading (X) and the ability to write (Y) u ntuk can find out how big the influence of interest in reading students majoring in science to Ability 's write in learning Indonesian in BC A State 5 Lebong, the authors conducted a study on students majoring in science in high school $\mathrm{N}$ egeri 5 Lebong by way of distributing a questionnaire (questionnaire) to variable $\mathrm{X}$ (interest in reading) and provide a test for the variable Y (write) .

The data in this study came from 65 students as the research sample where students were asked to fill out a questionnaire of 26 items for the variable $X$ (reading interest) which was valid and reliable. And for the $\mathrm{Y}$ variable, students were asked to do a test question, namely to write a poetry text. The following are the results of research that has been carried out by the author on the research sample, namely students of the Science Department of SMA Negeri 5 Lebong:

\section{a. Variable X (Students Reading Interest)}


The following table shows the results of the calculation of descriptive statistical tests for variable $\mathrm{X}$ (reading interest) using the SPSS version 20 application , as follows:

\section{Table 4.1}

Statistics

\begin{tabular}{|c|c|c|}
\hline \multicolumn{3}{|c|}{ Variable X (Reading Interest) } \\
\hline & Valid & 65 \\
\hline $\mathrm{N}$ & Missing & 0 \\
\hline \multicolumn{2}{|c|}{ mean } & 79.89 \\
\hline \multicolumn{2}{|c|}{ median } & 810.03 \\
\hline \multicolumn{2}{|c|}{ Mode } & $83^{a}$ \\
\hline \multicolumn{2}{|c|}{ Std. Deviation } & 8,768 \\
\hline \multicolumn{2}{|c|}{ Variance } & 76.879 \\
\hline \multicolumn{2}{|c|}{ Range } & 40 \\
\hline \multicolumn{2}{|c|}{ Minimum } & 57 \\
\hline \multicolumn{2}{|c|}{ Maximun } & 97 \\
\hline \multicolumn{2}{|c|}{ Sum } & 5193 \\
\hline
\end{tabular}

From the table above we can know that a questionnaire filled out by 65 students as samples of variable X known value of the mean (average) of 79.89, the value of the median (middle value) amounted to 81,03 , nil ai mode (value the most frequent) is 83 , the standard deviation value is 8,768 , the variance value is 76,879 , the range value (the difference between the largest and smallest values ) is 40 , the minimum value for the $\mathrm{X}$ variable is 57 , the maximum value of the $\mathrm{X}$ variable is 97, and nil ai sum is 5193.

\section{b. Variable Y (Writing Ability)}

The following table shows the results of the calculation of descriptive statistical tests for the Y variable ( writing ability ) using the SPSS version 20 application as follows:

\section{Table 4.2}

Statistics

\begin{tabular}{|c|c|c|}
\hline \multicolumn{3}{|c|}{ Writing Ability } \\
\hline \multirow[t]{2}{*}{$\mathrm{N}$} & Valid & 65 \\
\hline & Missing & 0 \\
\hline \multicolumn{2}{|c|}{ mean } & 82.18 \\
\hline \multicolumn{2}{|c|}{ median } & 84.00 \\
\hline \multicolumn{2}{|c|}{ Mode } & 85 \\
\hline \multicolumn{2}{|c|}{ Std. Deviation } & 7,909 \\
\hline \multicolumn{2}{|c|}{ Variance } & 62.559 \\
\hline \multicolumn{2}{|c|}{ Range } & 31 \\
\hline \multicolumn{2}{|c|}{ Minimum } & 64 \\
\hline \multicolumn{2}{|c|}{ Maximum } & 95 \\
\hline \multicolumn{2}{|c|}{ Sum } & 5342 \\
\hline
\end{tabular}


While v ariabel Y known to the mean value of 82.18 , the median value of 84 , 00 , the value of a standard deviation of 7,909 , amounting to 62.559 variance value, the value range is 31 , the minimum value for the variable $\mathrm{Y}$ is 64 , the maximum value for the variable $\mathrm{Y}$ is 95 and the sum value is 5342 .

\section{Data Analysis Prerequisite Test}

To find out how much influence the reading interest of students majoring in Science has on writing skills in Indonesian language learning at SMA Negeri 5 Lebong, it is necessary to do a prerequisite analysis test first, the analysis prerequisite test consists of three tests, namely homogeneity test, normality test and linearity test. . The following analysis prerequisite tests have been carried out:

\section{a. Homogeneity Test}

The homogeneity test was carried out with the help of the SPSS version 20 program. This homogeneity test used the Levene method. The following table of homogeneity test results:

Table 4.3

Homogeneity Test Results

\begin{tabular}{|r|rr|rr|rr|}
\hline \multicolumn{7}{|c|}{ Test of Homogeneity of Variances } \\
\hline Writing Ability & df1 & df2 & \multicolumn{2}{l|}{ Sig. } \\
\hline $\begin{array}{c}\text { Levene } \\
\text { Statistics }\end{array}$ & df1 & & & &, 142 \\
\hline 1.545 & & 15 & & 35 & & \\
\hline
\end{tabular}

In the SPSS table above, it is known that the significance value of the test of homogeneity of variances from this research data is $0.142>0.05$, so it can be concluded that the variance between the data is homogeneous.

\section{b. Normality test}

This normality test was carried out in order to know that the research had data that were normally distributed. Normal criteria can be met if the significance value obtained is more than 0.05 , then the data is normally distributed. Meanwhile, if the significance value obtained is less than 0.05 then the research data is not normally distributed. The normality test was carried out with the SPSS version 20 program using the Kolmogorov Smirnov Z method, which can be seen in the table below:

\section{Table 4.4}

Normality Test Results

\begin{tabular}{|l|l|}
\hline \multicolumn{2}{|c|}{ One-Sample Kolmogorov-Smirnov Test } \\
\hline & \\
& \multicolumn{2}{|c|}{ Unstandardized Residual } \\
\hline $\mathrm{N}$ & \multicolumn{1}{|c|}{65} \\
\hline
\end{tabular}




\begin{tabular}{|l|l|r|}
\hline Normal Parameters a,b & mean &, 0000000 \\
\cline { 2 - 3 } & Std. Deviation & 6.54352046 \\
\hline \multirow{2}{*}{$\begin{array}{l}\text { Most Extreme } \\
\text { Differences }\end{array}$} & Absolute &, 067 \\
\cline { 2 - 3 } & Positive & 0.060 \\
\cline { 2 - 3 } & negative &,- 067 \\
\hline Kolmogorov-Smirnov Z &, 544 \\
\hline asymp. Sig. (2-tailed) &, 929 \\
\hline \multicolumn{2}{|l|}{ a. Test distribution is Normal. } \\
\hline \multicolumn{2}{|l}{ b. Calculated from data. } \\
\hline
\end{tabular}

From the table above, it is known that the significance value of the test of normality obtained is 0.929 which is greater than 0.05 . So it can be interpreted that the data is normally distributed.

\section{c. Linearity Test}

The linearity test was carried out in order to find out whether there was a linear relationship between the reading interest variable $(\mathrm{X})$ and the writing ability variable $(\mathrm{Y})$. The two variables are said to have a linear relationship if their significance value is greater than 0.05 . This linearity test was carried out with the Test for Linearity with a significance level of 0.05 using the program //SPSS//version//20. Below is the table of results from the regression linearity test:

\section{Table 4.5}

\section{Result of Test Linearity}

\begin{tabular}{|c|c|c|c|c|c|c|c|}
\hline \multicolumn{8}{|c|}{ ANOVA Table } \\
\hline & & & $\begin{array}{c}\text { Sum of } \\
\text { Squares }\end{array}$ & df & $\begin{array}{l}\text { Mean } \\
\text { Square }\end{array}$ & $\mathrm{F}$ & Sig. \\
\hline \multirow{5}{*}{$\begin{array}{l}\text { Writing } \\
\text { Ability * } \\
\text { Reading } \\
\text { Interest }\end{array}$} & \multirow{3}{*}{$\begin{array}{l}\text { Between } \\
\text { Groups }\end{array}$} & (Combined) & 2643,335 & 29 & 91.149 & 2,345 & ,008 \\
\hline & & linearity & 1263,454 & 1 & 1263,454 & 32.505 &, 000 \\
\hline & & $\begin{array}{l}\text { Deviation } \\
\text { from } \\
\text { Linearity }\end{array}$ & 1379,880 & 28 & 49,281 & 1,268 & 251 \\
\hline & \multicolumn{2}{|c|}{ Within Groups } & 1360,450 & 35 & 38,870 & & \\
\hline & \multicolumn{2}{|c|}{ Total } & 4003.785 & 64 & & & \\
\hline
\end{tabular}

According to the table of output SPSS it can be known the value significance obtained amounted to 0.251 greater than 0,05 . Of the value of the significance that the interest in reading $(\mathrm{X})$ and the ability to write $(\mathrm{Y})$ have a relationship that is linear.

\section{Hypothesis test}


Hypothesis testing in this study is a simple regression test. Simple regression test was used to assess whether students' reading interest $(\mathrm{X})$ had an effect on writing ability $(\mathrm{Y})$ at SMA Negeri 5 Lebong. This simple regression test uses the help of the SPSS version 20 program. This simple regression test is carried out to find out:

\section{Effect of Interest Read Student Programs IPA on Writing Ability in Learning} Indonesian SMAN 5 Lebong

To determine whether the effect on the students' interest in learning writing skills language Indonesia SMAN 5 Lebong, it can be seen in the table below is:

Table 4.6

T. Test Results

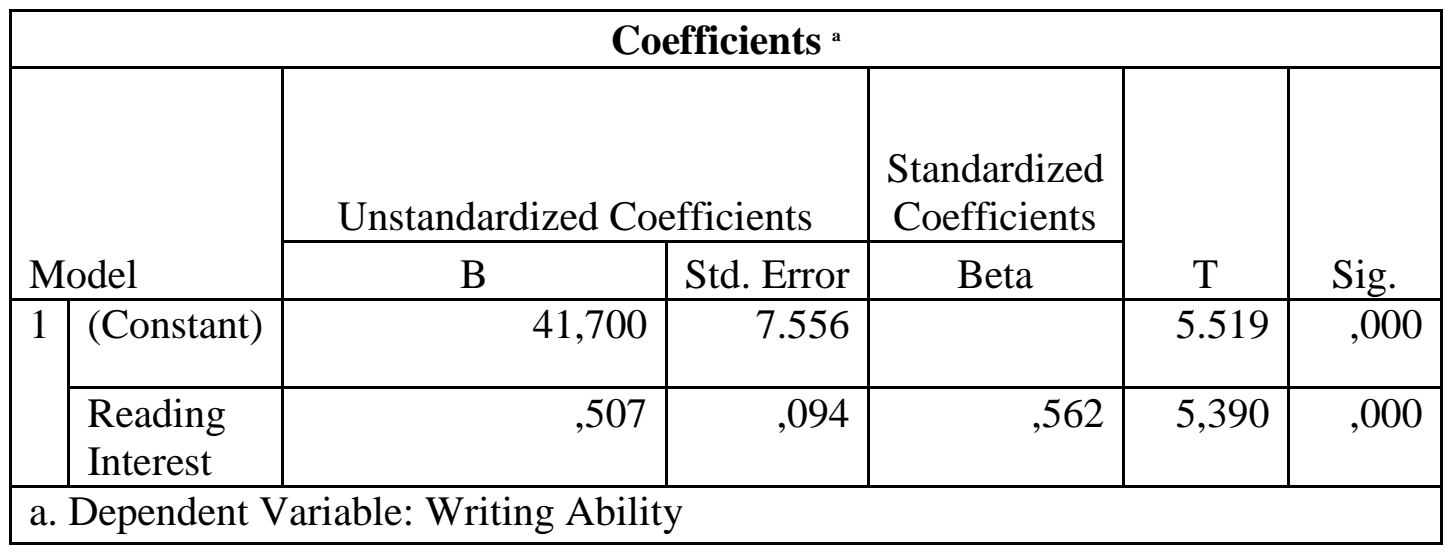

From the Coefficients table above, it is known that the B constant (constant value) is 41.700 , while the value of the independent variable $(\mathrm{X})$ is 0.507 , then the equation is obtained, namely :

$=\mathrm{a}+\mathrm{bX}$

$\hat{\mathrm{Y}}=41.700+0,507 \mathrm{X}$

The coefficient $\mathrm{B}$ is called the regression direction coefficient and states the direction of the change in the average variable $\mathrm{X}$ for each change in the $\mathrm{Y}$ variable. From the above equation, it is known that the constant value is 41,700 . The coefficient $b$ is called the coefficient. The results of the calculation table above $b=0.507$ is a positive sign contained in the coefficient of the independent variable (reading interest) which shows that if there is every time the reading interest variable increases by one, then the writing ability variable (Y) increases or also increases by 0.507 .

In addition to describing the regression equation, the table above also displays the significance test and t test, which is to find out whether there is a real or significant effect of variable $\mathrm{X}$ (reading interest) on variable $\mathrm{Y}$ (writing ability). The value of $\mathrm{t}$ can be used as an indication to answer the following hypothesis :

a. Ho (null hypothesis): There is no effect between interest in reading students majoring in science on students' writing skills in learning language Indonesia SMAN 5 Lebong. 
b. Ha (alternative hypothesis): There is influence between interest in reading students majoring in science learning in the ability to write in a language Indonesia SMAN 5 Lebong.

The basis for decision making for the $\mathrm{t}$-test is if the $\mathrm{t}-{ }_{\text {count }}$ value is greater than $\mathrm{t}{ }_{\text {table }}$ then there is a significant effect and if the $\mathrm{t}$ - count value is smaller than $\mathrm{t}$ t $_{\text {table, }}$, then there is no significant effect.

From table at the top of the there is a column of $\mathrm{T}$ called $\mathrm{T}_{\text {count }}$ is 5.519 and $\mathrm{t}_{\text {table }} 1,998$, the value of $\mathrm{t}_{\text {coun }} 5.519>\mathrm{t}_{\text {table }} 1,998$, so it can be concluded that $\mathrm{H}_{\text {or }}$ rejected and $\mathrm{H}_{\mathrm{a}}$ acceptability of the means "There is an effect of reading interest $(\mathrm{X})$ on writing ability $(\mathrm{Y})$ in learning Indonesian at SMA Negeri 5 Lebong" this is also reinforced by the data obtained from the significance test result is $0.000<0.05$. So this is in accordance with the basis of the decision is if the acquisition value ( $\mathrm{Sig}$ ) $>0.05$ then Ho is accepted and if the acquisition value ( $\mathrm{Sig}$ ) $<0.05$, then $\mathrm{Ho}$ is rejected and $\mathrm{Ha}$ is accepted. So it can be concluded that the reading interest of students majoring in science has an effect on writing skills in learning Indonesian.

\section{Magnitude of the Influence of Reading Interest of Science Majors on Ability in Learning Indonesian at SMA Negeri 5 Lebong}

The R square test was carried out by the author using the SPSS version 20 program. To find out how much influence reading interest $(\mathrm{X})$ had on writing ability $(\mathrm{Y})$ in simple regression analysis, it can be seen in the table below:

Table 4.7

R Square Test Results

\begin{tabular}{|l|c|r|r|rr|}
\hline \multicolumn{2}{|c|}{ Model Summary } \\
\hline Model & $\mathrm{R}$ & R Square & $\begin{array}{c}\text { Adjusted } \\
\text { R Square }\end{array}$ & \multicolumn{2}{c|}{$\begin{array}{c}\text { Std. Error of the } \\
\text { Estimate }\end{array}$} \\
\hline 1 & $.562^{\text {a }}$ & \multicolumn{2}{|c|}{, 316} &, 305 & 6.595 \\
\hline \multicolumn{2}{|l}{ a. Predictors: (Constant), Reading Interest } \\
\hline
\end{tabular}

In the table above, it can be seen that the calculation results of $\mathrm{R}$ square or $\mathrm{R} 2$ contained in the SPSS model summary table are 0.316 . The value of $\mathrm{R}$ square explains that the effect of students' reading interest (X) on writing ability (Y) in learning Indonesian at SMA Negeri 5 Lebong is $31.6 \%$ while $68.4 \%$ of writing ability is influenced by other variables not examined. It can be deduced that the positive influence students' interest $(\mathrm{X})$ to the ability to write $(\mathrm{Y})$ premises $\mathrm{n}$ total effect amounted to $31,6 \%$.

\section{Discussion}


Interest in reading is a very strong desire in a person accompanied by one's efforts to read (Farida Rahim, 2008). A strong interest in reading can certainly be realized by his willingness to get reading material and then read it at his own will without coercion from others. In developing reading skills, it should be followed by writing activities. Because reading and writing are a unit that will be good if done together. In line with this, Tarigan explained that writing is a language skill that is used to communicate indirectly, not face to face with other people. Writing is also a productive and expressive activity (Henry Guntur Tarigan, 1994). An example of the results of students' writing skills is writing poetry. Poetry is the result of literary art whose words are arranged according to certain conditions by using rhythm, rhyme, and figurative words (Kinayati Djojosuroto, 2005).

This study was conducted to determine the effect of reading interest in science majors on writing skills in Indonesian language learning at SMA Negeri 5 Lebong. This research was conducted by distributing instruments in the form of a questionnaire for the variable $\mathrm{X}$ (interest in reading) and a test for the variable $\mathrm{Y}$ (writing ability), namely the poetry writing test. The students' reading interest data was obtained using a questionnaire consisting of 26 questionnaire items that were declared valid for the $\mathrm{X}$ variable (reading interest) and the highest score for the $\mathrm{X}$ variable was 97 and the lowest value was 57, while the highest score for the Y variable was 95 and the lowest value is 64 .

The results of the distribution of questionnaires and tests will be tested with a prerequisite analysis test. First, the homogeneity of the data will be tested. From the results of the homogeneity test of the data, it is known that the data is homogeneous. It can be seen from the acquisition value ( $\mathrm{sig}$ ) of each variable is $0.142>0.05$, it can be concluded that the variance between the data is homogeneous. The next test is the normality test, the test results are seen from the acquisition value (sig) of the variables ( $\mathrm{X}$ and Y), namely $0.929>0.05$, it can be interpreted that the data is normal. Test prasy a rat next is the linearity test. The results of the linearity test showed that the data had a linear relationship between the $X$ variable (reading interest) and Y (writing ability). The data can be seen from the significance value of $0.251>0.05$.

After the three tests were carried out, the hypothesis was tested using a simple regression test. $U$ ntuk mengeahui whether avariable interestin reading $(\mathrm{X})$ effect on the variable abi pua $\mathrm{n}$ write $(\mathrm{Y})$. The results obtained from the simple regression test that the regression equation is known to have a constant value of 41.700 . The coefficient $b$ is referred to as the coefficient and the known value of $b=0.507$ marked positive contained in the coefficient of variable -free (interest read) that indicates if terda pat every time a variable interest in reading be rtambah sat $u$, then the variable ability to write $(Y)$ increased or incremented by one of 0.507 with the addition being significant. 
In addition, it is known that the calculated $\mathrm{T}$ value is 5.519 and the $\mathrm{t}$ table is 1.998 , then the t-count value is 5.519 > from t table 1.998, so it can be concluded that Ho is rejected and $\mathrm{Ha}$ is accepted which means "There is an influence of reading interest (X) on writing ability (Y) in learning Indonesian at SMA Negeri 5 Lebong" this is also reinforced by the data obtained from the significance test results are $0.000<0.05$. So this is in accordance with the basis of decision making is if the acquisition value (Sig) $>0.05$ then Ho is accepted and if the acquisition value ( $\mathrm{Sig})<0.05$, then $\mathrm{Ho}$ is rejected and $\mathrm{Ha}$ is accepted. So it can be concluded that .interest.reading.affects the ability to write in Indonesian language learning.

From the results of the calculation of $\mathrm{R}$ square of 0.316 . The value of $\mathrm{R}$ square shows that there is an effect of students' reading interest (X) on writing ability (Y) in learning Indonesian at SMA Negeri 5 Lebong is $31.6 \%$ while $68.4 \%$ writing ability is influenced by other variables not examined.

Therefore the research results presented above it can be concluded that "is there a significant between reading interest of students majoring in science to writing skills in learning language In donesia in SMAN 5 Lebong".

\section{Conclusion}

Based on data analysis has been done above it can be concluded that there is significant influence between science major students' interest towards writing skills in learning language Indonesia SMAN 5 Lebong. This can be seen from the results of hypothesis testing conducted with a simple regression test. The calculation results show that $b=0.507$, which means that every time the reading interest variable increases by one, the average writing ability variable increases by 0.507 . While the value of $\mathrm{t}_{\text {count }}$ obtained are 5.519 and $\mathrm{t}_{\text {table }} 1,998$, the value of $\mathrm{t}_{\text {count }} 5.519>\mathrm{t}_{\text {table }} 1,998$, so it can be concluded that $\mathrm{H}_{\mathrm{o}}$ rejected and $\mathrm{H}_{\mathrm{a}}$ acceptability which means "There is the influence of interest in reading $(\mathrm{X})$ to the ability to write $(\mathrm{Y})$ in learning Indonesian at SMA Negeri 5 Lebong". While the results perhit uungan $R$ square of 0.316 . The value of $\mathrm{R}$ square shows that there is an effect of students' reading interest $(\mathrm{X})$ on writing ability (Y) in learning Indonesian at SMA Negeri 5 Lebong is $31.6 \%$ while $68.4 \%$ writing ability is influenced by other variables not examined.

\section{References}

Arikunto, S. (2019). Research Procedures A Practical Approach . Jakarta: Reneka Cipta. Dalman. (2017). Reading Skills . Jakarta: King Grafindo.

Dalman. (2015). Writing Skills . Jakarta: Raja wali Pres.

Darmono. (2001). Management and Administration of School Libraries. Jakarta: Grasindo. Djojosuroto, K. (2005). Poetry Approach and Learning . Bandung: Shades. 
Kasiyun, S. (2015). Efforts to Increase Reading Interest as a Means to Educate the Nation. Indonesian Pen Journal Vol. 1 No. 1. file:///C:/Users/hp/Downloads/140-1772-PB.pdf . Retrieved February 16, 2021.

Muhtadi, A.S. (2017). Applicative Guidelines for Research Methods in the Preparation of Scientific Works, Thesis, Thesis, and Dissertations. Bandung: CV Setia Pustaka.

Naim, N. (2013). The Power of Reading : Exploring the Power of Reading to Boost Your Potential . Yogyakarta: Aura Pustaka.

Riduwan. (2019). Easy Learning Research for Teachers-Employees and Beginner Researchers . Bandung: Alphabeta.

Sugiyono. (2019). Quantitative and Qualitative Research Methods and R\&D. Bandung: Alphabeta.

Tarigan, H.T. (1994). Writing as One of the Language Skills . Bandung: Space.

Wiranta, S, V. (2020). Complete, Practical, and Easy to Understand Research Methodology . Yogyakarta: New Press Library. 